Удк 615.19 .072

\title{
ИССЛЕДОВАНИЕ АМИНОКИСЛОТНОГО СОСТАВА ИЗВЛЕЧЕНИЙ ИЗ РАСТИТЕЛЬНЫХ ОБЪЕКТОВ
}

\author{
() О.В. Тринеева*, А.В. Синкевич, А.И. Сливкин \\ Воронежский государственный университет, ул. Студенческая, 3, Воронеж, \\ 394006 (Россия), e-mail: trineevaov@mail.ru
}

\begin{abstract}
Проведено исследование и сравнительный анализ аминокислотного состава (свободные и связанные аминокислоты) плодов облепихи крушиновидной различных способов консервации и листьев крапивы двудомной с применением современных физико-химических методов (тонкослойная хроматография и капиллярный электрофорез). Предложена методика определения и разделения аминокислот методом тонкослойной хроматографии в извлечениях из лекарственного растительного сырья (на примере плодов облепихи крушиновидной и листьев крапивы двудомной). Полученные результаты могут служить дополнительным критерием качества сырья, так как любые отступления от технологического регламента при его заготовке, сушке, хранении и изготовлении лекарственных форм сказываются на хроматографическом профиле.

Ключевые слова: аминокислоты, плоды облепихи крушиновидной свежие и высушенные, листья крапивы двудомной, тонкослойная хроматография, капиллярный электрофорез.
\end{abstract}

\section{Введение}

Исследования химического состава и фармакологических свойств лекарственного растительного сырья (ЛРС), суммарных фитопрепаратов и индивидуальных веществ, выделенных из растений, приводят к созданию новых высокоэффективных лекарственных средств и открывают новые источники их получения [1]. В растениях, как показали последние исследования, содержится в свободном или связанном состоянии около $30 \%$ аминокислот (АК) (в пересчете на белок). Широкое распространение АК в растениях и их высокая биологическая активность способствуют эффективному действию на организм ЛРС и полученных из него препаратов. При этом АК в составе сопутствующих веществ способствуют улучшению всасывания, пролонгации терапевтического эффекта и потенцированию действия основных растительных компонентов [1]. Поэтому изучение качественного и количественного состава АК в ЛРС имеет практическое значение и вызывает научный интерес.

Анализ литературы за последние 10 лет показал, что при контроле качества лекарственных препаратов, содержащих АК, предпочтение отдается физико-химическим методам как наиболее экспрессным, чувствительным и информативным [2-13]. Обнаружение АК в различных объектах обычно проводят методом бумажной хроматографии. Определение качественного состава и количественного содержания устанавливают методом высокоэффективной жидкостной хроматографии на аминокислотном анализаторе [8-13]. Тонкослойная хроматография (ТСХ) в настоящее время в фармацевтическом анализе применяется для оценки подлинности и чистоты субстанций и лекарственных форм. ТСХ, обладая всеми преимуществами хроматографических методов, находит широкое применение в виду своей экспрессности, доступности, достаточной чувствительности, селективности, малой стоимости и простоте выполнения анализа. В по-

Тринеева Ольга Валерьевна - доцент кафедры фармацевтической химии и фармацевтической технологии, e-mail: trineevaov@ mail.ru Синкевич Анастасия Вячеславовна - студент Сливкин Алексей Иванович - декан фармацевтического факультета, заведующий кафедрой фармацевтической химии и фармацевтической технологии, профессор следнее время стали появляться публикации, свидетельствующие о возможности количественного анализа данных ТСХ с применением специализированного программного обеспечения [1, 4-6]. Нашли широкое применение также спектральные методы анализа (спекторфотометрия в УФ и видимой обла-

\footnotetext{
* Автор, с которым следует вести переписку.
} 
стях, фотоэлектроколориметрия). Недостатками указанных спектральных способов являются: громоздкость и длительность определений, нестабильность окрашенных продуктов цветных реакций, недостаточная чувствительность и селективность, невозможность определения АК при совместном присутствии без предварительного разделения [2, 7, 8].

В настоящее время согласно нормативной документации (НД) ЛРС крапивы двудомной и облепихи крушиновидной не стандартизируется по содержанию АК [14], составляющих значительную долю гидрофильной фракции. Так, суммарное содержание свободных АК в различных образцах сырья крапивы двудомной и крапивы жгучей составляет от 10,8 до 68,9 мкг/мг, содержание связанных АК - от 15,3 до 154,1 мкг/мг [15]. Поэтому необходимо учитывать данный показатель при разработке новых проектов и изменении уже существующих фармакопейных статей на ЛРС.

Цель работы - исследование аминокислотного состава ЛРС (на примере листьев крапивы двудомной и плодов облепихи крушиновидной) современными физико-химическими методами.

\section{Экспериментальная часть}

Объектом исследования являлось измельченное высушенное ЛРС крапивы двудомной отечественного производителя, соответствующее требованиям НД, а также свежие и высушенные плоды облепихи крушиновидной, собранные в Воронежской области в период полного созревания, согласно правилам заготовки данного вида ЛРС. Сушку плодов производили при $\mathrm{t}=60{ }^{\circ} \mathrm{C}$ до остаточной влажности не более $20 \%$.

Получение извлечения из листьев крапивы двудомной. Около 2,5 г измельченного сырья (точная навеска) с размером частиц, проходящих сквозь сито с диаметром отверстий 0,5 мм, помешают в коническую колбу вместимостью 100 мл, прибавляют 30 мл воды очищенной (с учетом коэффициента водопоглощения сырья). Колбу присоединяют к обратному холодильнику, нагревают на кипящей водяной бане в течение 30 мин, периодически встряхивая для смывания частиц сырья со стенок. Затем колбу с содержимым охлаждают до комнатной температуры. Извлечение фильтруют через несколько слоев марли, отжимая частицы сырья, в мерную колбу вместимостью 25 мл. При необходимости доводят объем до метки очищенной водой.

Получение извлечения из плодов облепихи крушиновидной. Около 10,0 г (точная навеска) свежих или высушенных измельченных плодов облепихи крушиновидной помещают в колбу вместимостью 100 мл, заливают 50 мл воды очищенной. Колбу присоединяют к обратному холодильнику, нагревают на кипящей водяной бане в течение 60 мин, периодически встряхивая для смывания частиц сырья со стенок. Затем колбу с содержимым охлаждают до комнатной температуры. Извлечение фильтруют через несколько слоев марли, отжимая ЛРС, в мерную колбу вместимостью 50 мл. При необходимости доводят объем до метки очищенной водой.

Проведение предварительного качественного анализа подтвердило присутствие АК в исследуемых извлечениях. Нингидриновая проба - цветная реакция на вещества, содержащие первичные и вторичные аминогруппы, и не является специфичной только для АК, а применяется также для определения аминокислот, аминов и других соединений. Однако согласно литературным данным, основными классами водорастворимых биологически активных веществ (БАВ) в исследуемых видах ЛРС являются флавоноиды, дубильные вещества, органические кислоты, хлорофиллы, стеролы, лигнаны и минеральные соли. Плоды облепихи, кроме вышеперечисленных БАВ, содержат значительное количество жирного масла, богатого фосфолипидами (содержат аминогруппы), которые в водную вытяжку не извлекаются. Поэтому предполагаем, что полученное окрашивание обусловлено присутствием АК [16].

\section{Обсуждение результатов}

На первом этапе проводили исследование состава свободных АК в изучаемом ЛРС, извлекаемых водой. Согласно рекомендациям литературы, в качестве реагента для обнаружения зон АК использовали 0,2\%-ный раствор нингидрина в ацетоне, который образует с АК аммонийную соль енольной формы дикетогидринденкетогидринамина, имеющую стойкую сине-фиолетовую окраску [16]. В эксперименте изучено более пятнадцати типов элюирующих систем, рекомендованных в научной литературе для разделения АК [1, 4-6] в широком диапазоне полярности. Наилучшее разделение и качество хроматографических зон было достигнуто в системе $н$-бутанол - кислота уксусная ледяная - вода (4:1:2) со значением полярности 5,69 [17] при высоте пробега элюента не менее 13 см. 
Полученные извлечения из исследуемого ЛРС наносили на стартовую линию хроматографических пластин марок «Sorbfil» ПТСX-П-А размером $10 \times 15$ см в количествах 10 и 5 мкл. Вид полученных хроматограмм представлен на рисунке 1.

Для каждой хроматографической зоны были рассчитаны величины $\mathrm{R}_{\mathrm{f}}$, коэффициенты распределения $(K)$ и селективности сорбции $(\mathrm{L})$, высота, эквивалентная теоретической тарелке $(\mathrm{H})$, число теоретических тарелок (N) (табл. 1). В случае изучения состава АК и выделения отдельных компонентов с использованием метода ТСХ, селективность сорбции является основной характеристикой эффективности процесса. Разделение двух соседних зон считается полным при $\mathrm{L} \geq 1$ [18]. Идентификация зон на хроматограммах в сравнении с достоверными стандартными образцами $(0,1 \%$ водные растворы АК: аргинин, глицин, глутаминовая кислота, пролин, фенилаланин, метионин, валин, лейцин) представлена в таблице 1.

На хроматограммах извлечения из листьев крапивы двудомной обнаружены зоны (рис. 1) заменимых АК со значениями величин $\mathrm{R}_{\mathrm{f}}=0,20 \pm 0,02$ (аргинин); 0,30 $\pm 0,02$ (пролин); 0,35 $\pm 0,04$ (глицин); $0,42 \pm 0,02$ (глутаминовая кислота); и незаменимых АК со значениями величин $\mathrm{R}_{\mathrm{f}}=0,46 \pm 0,02$ (валин); $0,56 \pm 0,06$ (метионин); $R_{f}=0,63 \pm 0,02$ (лейцин). Зоны $\mathrm{AK}$ со значениями величин $\mathrm{R}_{\mathrm{f}}=0,14 \pm 0,02$ и $0,25 \pm 0,02$ не идентифицированы.

Установлено, что состав свободных АК в извлечениях из высушенных и свежих плодов облепихи крушиновидной несколько отличен. На хроматограммах извлечений обнаружены общие зоны (рис. 1) заменимых АК со значениями величин $\mathrm{R}_{\mathrm{f}}=0,35 \pm 0,04$ (глицин); 0,30 $\pm 0,02$ (пролин); 0,42 $\pm 0,02$ (глутаминовая кислота); и незаменимых АК со значениями величин $\mathrm{R}_{\mathrm{f}}=0,46 \pm 0,02$ (валин); 0,56 $\pm 0,06$ (метионин); $\mathrm{R}_{\mathrm{f}}=0,63 \pm 0,02$ (лейцин) и $0,72 \pm 0,02$ (фенилаланин). При анализе извлечения из плодов облепихи высушенных обнаружены дополнительные характерные зоны неидентифицированных АК с величинами $\mathrm{R}_{\mathrm{f}}=0,06 \pm 0,005 ; \mathrm{R}_{\mathrm{f}}=0,14 \pm 0,02 ; \mathrm{R}_{\mathrm{f}}=0,25 \pm 0,02$, а также зона аргинина с $\mathrm{R}_{\mathrm{f}}=0,20 \pm 0,02$, отсугствующие на хроматограмме извлечения из свежих плодов (рис. 1). Свежие плоды содержат АК как в свободном, так и в связанном виде (белковые соединения). При высушивании при температуре $60{ }^{\circ} \mathrm{C}$ в клеточном соке ЛРС, богатом органическими кислотами [19], протекают процессы кислотного гидролиза, что может сопровождается изменением состава свободных АК в сырье. В связи с тем, что хроматограммы извлечений из ЛРС имеют неодинаковый вид (рис. 1), мы предполагаем, что хроматографический профиль АК можно использовать для стандартизации сырья.

Результаты расчета величины селективности сорбции свидетельствуют об удовлетворительном разделении хроматографических зон на хроматограмме и правомерности использования данной методики для исследуемых видов ЛРС (табл. 1).

Рис. 1. Вид хроматограммы извлечений: $1-$ из листьев крапивы двудомной (объем пробы 10 мкл); 2 - из плодов облепихи крушиновидной высушенных (объем пробы 5 мкл); 3 - из плодов облепихи крушиновидной свежих (объем пробы 10 мкл); 4 - смесь 0,1\%-ных водных растворов стандартных образцов АК (объем пробы 5 мкл) после проявления $0,2 \%$-ным раствором нингидрина в ацетоне:

1 - аргинин; 2 - пролин; 3 - глицин; 4 - глугаминовая кислота; 5 - валин; 6 - метионин; 7 - лейцин;

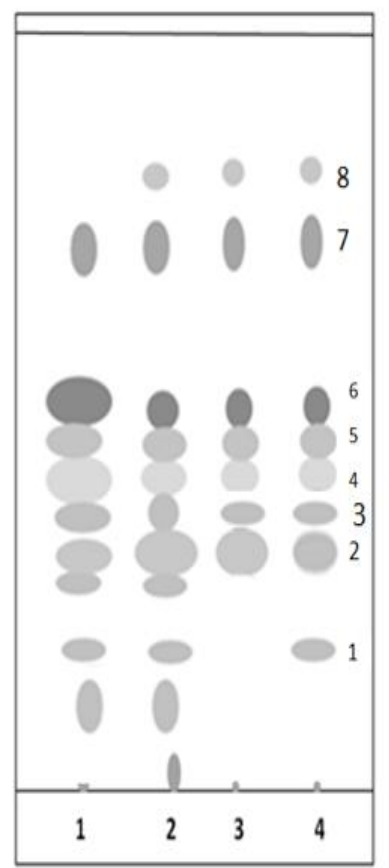

8 - фенилаланин 
Таблица 1. Идентификация хроматографических зон свободных АК на хроматограммах

\begin{tabular}{|c|c|c|c|c|c|c|c|}
\hline $\begin{array}{c}\text { № } \\
\text { зоны }\end{array}$ & $\mathrm{Rf}$ & K & $\mathrm{L}$ & $\mathrm{N}$ & $\mathrm{H}, \mathrm{MM}$ & Окраска в видимом свете & Идентификация АК \\
\hline \multicolumn{8}{|c|}{ Извлечение из листьев крапивы двудомной } \\
\hline 1 & 0,142 & 6,04 & - & 21,94 & 5,56 & розовая & Неидентифицированная АК \\
\hline 2 & 0,197 & 4,08 & 1,48 & 37,65 & 3,24 & розовая & Аргинин \\
\hline 3 & 0,244 & 3,10 & 1,32 & 31,28 & 3,90 & розовая & Неидентифицированная АК \\
\hline 4 & 0,299 & 2,34 & 1,32 & 32,19 & 3,79 & оранжевая & Пролин \\
\hline 5 & 0,354 & 1,82 & 1,29 & 45,35 & 2,69 & розовая & Глицин \\
\hline 6 & 0,409 & 1,44 & 1,26 & 99,19 & 1,23 & малиновая & Глутаминовая кислота \\
\hline 7 & 0,457 & 1,19 & 1,21 & 145,24 & 0,84 & сиреневая & Валин \\
\hline 8 & 0,520 & 0,92 & 1,29 & 156,41 & 0,78 & розовая & Метионин \\
\hline 9 & 0,610 & 0,64 & 1,44 & 369,70 & 0,33 & розово-сиреневая & Лейцин \\
\hline \multicolumn{8}{|c|}{ Извлечение из плодов облепихи крушиновидной высушенных } \\
\hline 1 & 0,063 & 14,87 & - & 39,68 & 3,13 & розовая & Неидентифицированная АК \\
\hline 2 & 0,143 & 5,99 & 2,48 & 62,00 & 2,00 & розовая & Неидентифицированная АК \\
\hline 3 & 0,198 & 4,05 & 1,48 & 48,44 & 2,56 & розовая & Аргинин \\
\hline 4 & 0,270 & 2,70 & 1,50 & 116,98 & 1,06 & розовая & Неидентифицированная АК \\
\hline 5 & 0,317 & 2,15 & 1,26 & 137,80 & 0,90 & оранжевая & Пролин \\
\hline 6 & 0,357 & 1,80 & 1,19 & 221,43 & 0,56 & розовая & Глицин \\
\hline 7 & 0,400 & 1,50 & 1,20 & 248,00 & 0,50 & малиновая & Глутаминовая кислота \\
\hline 8 & 0,440 & 1,25 & 1,22 & 275,56 & 0,45 & сиреневая & Валин \\
\hline 9 & 0,600 & 0,67 & 1,87 & 149,40 & 0,83 & розовая & Метионин \\
\hline 10 & 0,650 & 0,54 & 1,24 & 157,69 & 0,78 & розово-сиреневая & Лейцин \\
\hline 11 & 0,720 & 0,39 & 1,38 & 459,26 & 0,27 & розовая & Фенилаланин \\
\hline \multicolumn{8}{|c|}{ Извлечение из плодов облепихи крушиновидной свежих } \\
\hline 1 & 0,280 & 2,57 & - & 58,74 & 2,06 & оранжевая & Пролин \\
\hline 2 & 0,340 & 1,95 & 1,71 & 100,83 & 1,20 & розовая & Глицин \\
\hline 3 & 0,400 & 1,50 & 1,30 & 157,14 & 0,77 & малиновая & Глутаминовая кислота \\
\hline 4 & 0,455 & 1,20 & 1,25 & 186,15 & 0,65 & сиреневая & Валин \\
\hline 5 & 0,610 & 0,64 & 1,88 & 257,45 & 0,47 & розово-сиреневая & Метионин \\
\hline 6 & 0,650 & 0,54 & 1,19 & 157,69 & 0,78 & розово-сиреневая & Лейцин \\
\hline 7 & 0,740 & 0,34 & 1,59 & 224,07 & 0,54 & розовая & Фенилаланин \\
\hline
\end{tabular}

Для подтверждения правильности полученных результатов, а также исследования полного аминокислотного состава (свободные и связанные АК) на втором этапе работы изучаемые объекты анализировали методом капиллярного электрофореза (КЭ) на приборе «Капель-105/105М» («Люмэкс», СПб, Россия), для чего навески образцов гидролизовали $6 \mathrm{M}$ соляной кислотой при температуре $110 \pm 5^{\circ} \mathrm{C}$ в течение $16-$ 18 ч $[16,20]$. Метод основан на получении из свободных форм АК фенилизотиокарбамильных производных, дальнейшем их разделении и количественном определении (рис. 2). Условия разделения: буфер 30 мМ фосфатный, 4 мМ $\beta$-циклодекстрин ( $\mathrm{pH} 7,4)$; капилляр ( $\mathrm{L}_{э ф ф} / \mathrm{L}_{\text {общ }}=65 / 75 \mathrm{~cm}, \mathrm{ID}=50$ мкм); ввод пробы 150 мбар×c; напряжение +25 кВ; УФ-детектирование 254 нм; температура $30{ }^{\circ} \mathrm{C}[20]$.

Согласно данным таблицы 2, преобладающими АК в косточке плодов облепихи крушиновидной являются аспарагиновая и глутаминовая кислоты. Суммарное содержание АК плодов облепихи крушиновидной высушенных (с косточкой) составляет 11,83\%. Плоды без косточки (кожица и мякоть) в большом количестве содержат аргинин и пролин. Суммарное содержание АК плодов облепихи крушиновидной свежих (без косточки) составляет около 4,99\%. Данный результат свидетельствует о преимущественном содержании АК в белках семени. Неидентифицированные зоны свободных АК на хроматограммах извлечений (табл. 1), согласно литературным данным, и результатам исследования аминокислотного состава анализируемого сырья методом КЭ (табл. 2), предположительно могут относиться к лизину $\left(\mathrm{R}_{\mathrm{f}}=0,05 \pm 0,02\right)$ и серину $\left(\mathrm{R}_{\mathrm{f}}=0,15 \pm 0,02\right)[1]$.

Для исследования зависимости состава АК плодов облепихи крушиновидной от мест произрастания (табл. 2) использовали многочисленные литературные данные [21-23].

Анализ результатов состава АК в плодах облепихи различных мест произрастания (табл. 2) свидетельствует о значительной зависимости данного показателя от места произрастания растения [24, 25].

Представляет также интерес провести сравнительную характеристику содержания АК в листьях и других частях (стебли, цветки и трава) различных видов растения рода Urtica L. (табл. 3). Для этого полученные результаты были сравнены с литературными данными [26-28]. 


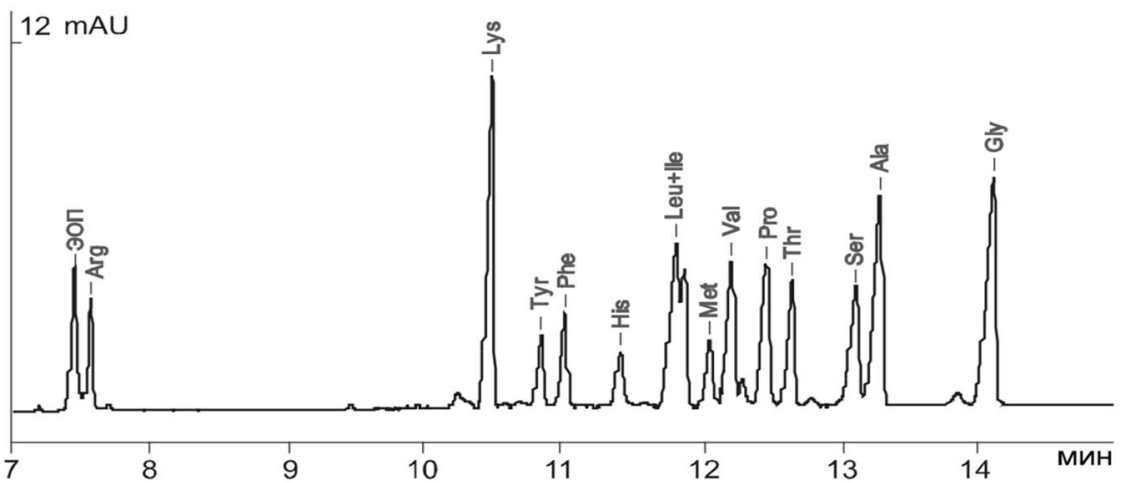

Рис. 2. Электрофореграмма аминокислот, полученная на системе для КЭ «Капель-105/105М»

Таблица 2. Аминокислотный состав исследуемых объектов (в пересчете на абсолютно сухое сырье)

\begin{tabular}{|c|c|c|c|c|c|}
\hline \multirow[b]{2}{*}{$\begin{array}{c}\text { № } \\
\Pi / \Pi\end{array}$} & \multirow[b]{2}{*}{ Аминокислота } & \multicolumn{4}{|c|}{ Содержание аминокислот, \% } \\
\hline & & $\begin{array}{c}\text { плоды облепихи } \\
\text { крушиновидной } \\
\text { (subsp. } \\
\text { turkestanica) [21] }\end{array}$ & $\begin{array}{c}\text { плоды облепихи } \\
\text { крушиновидной } \\
\text { (subsp. chinensis) } \\
{[21]}\end{array}$ & $\begin{array}{c}\text { плоды облепихи кру- } \\
\text { шиновидной высу- } \\
\text { шенные (с косточкой) } \\
{[16]}\end{array}$ & $\begin{array}{c}\text { свежие плоды } \\
\text { облепихи кру- } \\
\text { шиновидной } \\
\text { (без косточки) }\end{array}$ \\
\hline 1 & Аргинин & 0,04 & Не обнаружен & 1,17 & 0,80 \\
\hline 2 & Лизин* & 0,06 & 0,0005 & 0,49 & 0,14 \\
\hline 3 & Тирозин & 0,06 & 0,006 & 0,35 & 0,36 \\
\hline 4 & Фенилаланин* & 0,07 & 0,002 & 0,35 & 0,43 \\
\hline 5 & Гистидин & 0,02 & 0,005 & 0,29 & 0,22 \\
\hline 6 & Лейцин* & 0,06 & 0,002 & 0,60 & 0,43 \\
\hline 7 & Изолейцин* & 0,05 & 0,002 & 0,41 & 0,22 \\
\hline 8 & Метионин* & 0,03 & 0,05 & 0,06 & 0,07 \\
\hline 9 & Валин* & 0,07 & 0,08 & 0,43 & 0,22 \\
\hline 10 & Пролин & Не обнаружен & 0,03 & 0,49 & 0,72 \\
\hline 11 & Треонин* & 0,04 & 0,001 & 0,41 & 0,29 \\
\hline 12 & Серин & 0,05 & 0,01 & 0,60 & 0,36 \\
\hline 13 & Аланин & 0,03 & 0,09 & 0,46 & 0,14 \\
\hline 14 & Глицин & 0,04 & 0,009 & 0,44 & 0,22 \\
\hline 15 & Цистин & - & - & 0,35 & Менее 0,007 \\
\hline 16 & Глутаминовая кислота & 0,12 & 0,002 & 1,60 & 0,07 \\
\hline 17 & Аспарагиновая кислота & 0,17 & 0,03 & 3,33 & 0,29 \\
\hline
\end{tabular}

* Незаменимая аминокислота

Таблица 3. Содержание АК в листьях и других частях различных видов растения рода Urtica L., \%

\begin{tabular}{l|c|c|c}
\hline \multicolumn{1}{c|}{ Аминокислота } & $\begin{array}{c}\text { Экспериментальные } \\
\text { данные [16] }\end{array}$ & $\begin{array}{c}\text { Трава крапивы } \\
\text { двудомной [26] }\end{array}$ & $\begin{array}{c}\text { Листья крапивы } \\
\text { коноплевой [28] }\end{array}$ \\
\hline Аргинин & 1,23 & 2,51 & - \\
Лизин & 1,07 & 0,97 & 0,50 \\
Тирозин & 0,78 & 0,23 & 0,90 \\
Фенилаланин & 1,01 & 0,52 & 0,73 \\
Гистидин & 0,46 & 2,33 & 0,50 \\
Лейцин & 1,59 & 0,46 & 0,19 \\
Изолейцин & 0,90 & - & 0,82 \\
Метионин & 0,30 & - & - \\
Валин & 1,11 & 0,23 & 0,88 \\
Пролин & 1,03 & - & 0,84 \\
Треонин & 1,22 & 4,52 & 0,71 \\
Серин & 1,27 & 1,71 & 0,75 \\
Аланин & 1,47 & 0,35 & 0,33 \\
Глицин & 1,19 & - & 1,75 \\
Цистин & 0,63 & 1,66 & 1,62 \\
Глугаминовая кислота & 1,96 & 3,76 & \\
Аспарагиновая кислота & 2,99 & & \\
\hline
\end{tabular}

«-» нет данных. 
В исследуемом ЛРС крапивы двудомной преобладают аспарагиновая, глутаминовая кислоты, аргинин, лейцин, аланин, серин и треонин. В целом, листья крапивы двудомной являются более богатым источником АК по сравнению с плодами облепихи крушиновидной.

Анализ результатов состава АК различных органов крапивы двудомной и крапивы коноплевой (табл. 3) в очередной раз подтверждает систематическую и генетическую близость этих двух видов. Однако листья крапивы двудомной, по сравнению с листьями крапивы коноплевой, характеризуются большим содержанием АК. В траве крапивы двудомной, по сравнению с листьями, такие АК, как аргинин, гистидин, треонин и серин, представлены в большем количестве, что может свидетельствовать об их преимущественном накоплении в том или ином органе растения.

\section{Выводы}

1. Проведено исследование аминокислотного состава (свободные и связанные АК) плодов облепихи крушиновидной и листьев крапивы двудомной с применением современных физико-химических методов (ТСХ и КЭ).

2. С использованием параметров эффективности хроматогафического разделения веществ в тонком слое сорбента обоснован выбор оптимальной система для определения и разделения свободных АК методом ТСХ в извлечениях из ЛРС (на примере плодов облепихи крушиновидной и листьев крапивы двудомной).

3. Установлено, что набор АК индивидуален не только для каждого вида ЛРС, но и зависит от способа его консервации.

4. Хроматографический профиль АК извлечений из ЛРС можно использовать для оценки его доброкачественности. Полученные результаты могут служить дополнительным критерием качества ЛРС, так как любые отступления от технологического регламента при заготовке, сушке и хранении сырья, извлечения экстракта сказываются на хроматографическом профиле.

\section{Список литературы}

1. Кхалед Абу Захер, Журавлев Н.C. Аминокислотный состав некоторых видов растений рода Rumex L. // Провизор. 2001. №21. URL: http://www.provisor.com.ua/archive/2001/N21/art_23.php?part_code=14\&art_code=2823

2. Олешко Г.И., Ярыгина Т.И., Зорина Е.В., Решетникова М.Д. Разработка унифицированной методики количественного определения суммы свободных аминокислот в лекарственном растительном сырье и экстракционных препаратах // Фармация. 2011. №3. С. 14-17.

3. Губин К.В., Ханина М.А. Анализ аминокислотного и элементного состава надземной части и сухого экстракта Urtica cannabina L. // Медицина и образование в сибири. 2011. №5. [Электронный ресурс]. URL: http://ngmu.ru/cozo/mos/article/text_full.php?id=538

4. Патент №2095808 (РФ). Способ разделения и детектирования аминокислот / И.И. Малахова, В.Д. Красиков, Б.В. Тяглов, Е.В. Дегтерев. 1997.

5. Патент №2078342 (РФ). Способ разделения аминокислот в биологических жидкостях / Б.В. Тяглов, Е.В. Дегтерев, И.И. Малахова и др. 1997.

6. А. с. №1642373 (СССР). Способ определения аминокислот, модифицированных высшими жирными кислотами / В.Г. Голованов, А.А. Петровский, Н.В. Кельник и др. 1991.

7. Патент №2167410 (РФ). Способ количественного определения алифатических аминокислот / Т.И. Ярыгина, А.В. Захаров, В.А. Дубовик. 2001.

8. Khokhani K., Ram V., Bhatt J., Khatri T., Joshi H.. Spectrophotometric and chromatographic analysis of amino acids present in leaves of Ailanthus excels // International Journal of ChemTech Research. 2012. Vol. 4. N1. Pp. 389-393.

9. Elbashir A.A., Suliman F.E.O., Aboul-Enein H.Y.. The application of 7-chloro-4-nitrobenzoxadiazole and 4-fluoro-7nitro-2,1,3-benzoxadiazole for the analysis of amines and amino acids using High-Performance Liquid chromatography // GU J. Sci. 2011. Vol. 24(4). Pp. 679-697.

10. Rubio-Barroso S., Santos-Delgado M.J., Martin-Olivar C., Polo-Diez L.M. Inderect chiral HPLC determination and fluorimetric detection of d-amino acids in milk and oyster samples // J. Dairy Sci. 2006. Vol. 89. N1. Pp. 82-89.

11. Calabrese M., Stancher B., Riccobon P. High performance liquid chromatography determination of proline isomers in Italian wines // J. Sci. Food Agric. 1995. Vol. 69. Pp. 361-366.

12. Herbert P., Barros P., Ratola N., Alves A. HPLC determination of amino acids in musts and port wine using OPA FMOC derivatives // J. Food Sci. 2000. Vol. 65. Pp. 1130-1133.

13. Hernandez-Orte P., Ibarz M.J., Cacho J., Ferreira V. Amino acid determination in grape juices and wines by HPLC using a modification of the 6-aminoquinolyl-N-hydroxysuccinimidyl carbamate (AQC) method // Chromatographia. 2003. Vol. 58. Pp. 29-35.

14. Государственная фармакопея. Вып. 2. М., 1990. С. 274-275. 
15. Копытько Я.Ф., Лапинская Е.С., Сокольская Т.А. Применение, химический состав и стандартизация сырья и препаратов Urtica // Химико-фармацевтический журнал. 2011. Т. 45. №10. С. 32-40.

16. Тринеева О.В., Синкевич А.В., Сливкин А.И., Сафонова Е.Ф. Исследование аминокислотного состава извлечений из растительных объектов методом двумерной ТСХ // Сорбционные и хроматографические процессы. 2014. Т. 14, вып. 3. С. 530-536.

17. Рудаков О.Б., Востров И.А., Федоров С.В. и др. Спутник хроматографиста. Методы жидкостной хроматографии. Воронеж, 2004. 528 с.

18. Гейсс Ф. Основы тонкослойной хроматографии М., 1999. 405 с.

19. Тринеева О.В., Сафонова И.И., Сафонова Е.Ф., Сливкин А.И. Органические кислоты в плодах облепихи крушиновидной // Фармация. 2013. №7. С. 7-10.

20. Комарова Н.В., Каменцев Я.С. Практическое руководство по использованию систем капиллярного электрофореза «Капель». СПб., 2006. 212 с.

21. Cheng Tigong, Ni Ming Kang, Li Rong, Ji Fen. Исследование биохимических свойств среднеазиатской облепихи, произрастающей в провинции Ганьсу (КНР) // Химия природных соединений. 1991. №1. С. 135-137.

22. Золотарева А.М., Чиркина Т.Ф., Гончикова С.Д., Карпенко Л.Д. Химический состав облепихового шрота // Известия вузов. Пищевая технология. 1994. №1-2. С. 24-26.

23. Золотарева А.M. Основы ресурсосберегающей технологии переработки биомассы Hippophae rhamnoides L.: автореф. дисс. ... докт. техн. наук. Улан-Удэ, 2004. 32 с.

24. Солоненко Л.П., Лоскутова Г.А., Дружкова Т.А., Шёрсткин А.Ф. Свободные аминокислоты сока и семян облепихи // Новое в биологии, химии и фармакологии облепихи. Новосибирск, 1991. №6. С. 79-85.

25. Карпова Е.А. Изменчивость биохимического состава плодов облепихи крушиновидной при интродукции в лесостепь Западной Сибири: автореф. дисс. ... канд. техн. наук. Новосибирск, 1999. 25 с.

26. Яцюк В.Я., Чалый Г.А., Сошникова О.В. Биологически активные вещества травы крапивы двудомной // Российский медико-биологический вестник имени академика И.П. Павлова. 2006. №1. С. 25-29.

27. Скалозубова Т.А. Изучение метаболома сырья и лекарственных форм крапивы двудомной: автореф. дисс. ... канд. фарм. наук. М., 2013. 23 с.

28. Пецуха В.С. Фармакогностическое изучение крапивы коноплевой (Urtica cannabina L.): автореф. дисс. ... канд. фарм. наук. Улан-Удэ, 2009. 26 с.

Поступило в редакичию 24 февраля 20142.

После переработки 29 декабря 2014 г. 
Trineeva O.V.*, Sinkevych A.V., Slivkin A.I. STUDY OF THE AMINO ACID COMPOSITION OF PLANT EXTRACTS OBJECTS

Voronezh State University, ul. Studencheskaja, 3, Voronezh, 394006 (Russia), e-mail: trineevaov@mail.ru.

The research and comparative analysis of amino acid composition (free and bound amino acids) fruits of Hippophaes rhamnoides various methods of preserving and folia Urticae dioicae with modern physics-chemical methods (thin layer chromatography and capillary electrophoresis). The method of determination and separation of amino acids by thin-layer chromatography in extracts of medicinal plants (for example, fruit of Hippophaes rhamnoides and folia Urticae dioicae). The results obtained may serve as an additional criterion for the quality of raw materials, as any deviation from the technological regulations when harvesting, drying, storage and manufacture of dosage forms affect the chromatographic profile.

Keywords: amino acids, fruit of Hippophaes rhamnoides fresh and dried, folia Urticae dioicae, thin layer chromatography, capillary electrophoresis.

\section{References}

1. Khaled Abu Zaher, Zhuravlev N.S. Provizor, 2001, no. 21, URL: http://www.provisor.com.ua/archive/2001/N21/ art_23.php?part_code $=14 \&$ art_code $=2823$ (in Russ.).

2. Oleshko G.I., Jarygina T.I., Zorina E.V., Reshetnikova M.D. Farmacija, 2011, no. 3, pp. 14-17. (in Russ.).

3. Gubin K.V., Hanina M.A. Medicina i obrazovanie v sibiri, 2011, no. 5, URL: http://ngmu.ru/cozo/mos/article/ text_full.php?id=538 (in Russ.).

4. Patent 2095808 (RU). 1997. (in Russ.).

5. Patent 2078342 (RU). 1997. (in Russ.).

6. Patent 1642373 (SU). 1991. (in Russ.).

7. Patent 2167410 (RU). 2001. (in Russ.).

8. Khokhani K., Ram V., Bhatt J., Khatri T., Joshi H. International Journal of ChemTech Research. 2012, vol. 4, no. 1, pp. 389-393.

9. Elbashir A.A., Suliman F.E.O., Aboul-Enein H.Y. GU J. Sci. 2011, vol. 24(4), pp. 679-697.

10. Rubio-Barroso S., Santos-Delgado M.J., Martin-Olivar C., Polo-Diez L.M. J. Dairy Sci. 2006, vol. 89, no. 1, pp. 82-89.

11. Calabrese M., Stancher B., Riccobon P. J. Sci. Food Agric. 1995, vol. 69, pp. 361-366.

12. Herbert P., Barros P., Ratola N., Alves A. J. Food Sci. 2000, vol. 65, pp. 1130-1133.

13. Hernandez-Orte P., Ibarz M.J., Cacho J., Ferreira V. Chromatographia. 2003, vol. 58, pp. 29-35.

14. Gosudarstvennaja farmakopeja. [State Pharmacopoeia]. Issue 2, Moscow, 1990, pp. 274-275. (in Russ.).

15. Kopyt'ko Ja.F., Lapinskaja E.S., Sokol'skaja T.A. Himiko-farmacevticheskij zhurnal, 2011, vol. 45, no. 10, pp. 32-40. (in Russ.).

16. Trineeva O.V., Sinkevich A.V., Slivkin A.I., Safonova E.F. Sorbcionnye i hromatograficheskie processy, 2014, vol. 14, no. 3, pp. 530-536. (in Russ.).

17. Rudakov O.B., Vostrov I.A., Fedorov S.V. Sputnik hromatografista. Metody zhidkostnoj hromatografii. [Satellite hromatografista. HPLC Methods]. Voronezh, 2004, 528 p. (in Russ.).

18. Gejss F. Osnovy tonkoslojnoj hromatografii. [Basics TLC]. Moscow, 1999, 405 p. (in Russ.).

19. Trineeva O.V., Safonova I.I., Safonova E.F., Slivkin A.I. Farmacija, 2013, no. 7, pp. 7-10. (in Russ.).

20. Komarova N.V., Kamencev Ja.S. Prakticheskoe rukovodstvo po ispol'zovaniju sistem kapilljarnogo jelektroforeza «Kapel'». [Practical guidance on the use of capillary electrophoresis systems "Kapel"']. Saint Petersburg, 2006, 212 p. (in Russ.).

21. Cheng Tigong, Ni Ming Kang, Li Rong, Ji Fen. Himija prirodnyh soedinenij, 1991, no. 1, pp. 135-137. (in Russ.).

22. Zolotareva A.M., Chirkina T.F., Gonchikova S.D., Karpenko L.D. Izvestija vuzov. Pishhevaja tehnologija. 1994, no. 1-2, pp. 24-26. (in Russ.).

23. Zolotareva A.M. Osnovy resursosberegajushhej tehnologii pererabotki biomassy Hippophae rhamnoides L.: avtoref. dokt. tehn. nauk. [Basics resource-saving technologies of biomass Hippophae rhamnoides L.: Author. diss. Doctor of Technical Sciences]. Ulan-Udje, 2004, 32 p. (in Russ.).

24. Solonenko L.P., Loskutova G.A., Druzhkova T.A., Shjorstkin A.F. Novoe v biologii, himii i farmakologii oblepihi. Novosibirsk, 1991, no. 6, pp. 79-85. (in Russ.).

25. Karpova E.A. Izmenchivost' biohimicheskogo sostava plodov oblepihi krushinovidnoj pri introdukcii v lesostep' Zapadnoj Sibiri: avtoref. kand. tehn. nauk. [The variability of the chemical composition of sea buckthorn fruits in the forest with the introduction of Western Siberia: Author. diss. Candidate of technical sciences]. Novosibirsk, 1999, 25 p. (in Russ.).

26. Jacjuk V.Ja., Chalyj G.A., Soshnikova O.V. Rossijskij mediko-biologicheskij vestnik imeni akademika I.P. Pavlova, 2006, no. 1, pp. 25-29. (in Russ.).

27. Skalozubova T.A. Izuchenie metaboloma syr'ja i lekarstvennyh form krapivy dvudomnoj: avtoref. kand. farm. nauk. [Learning metabolome of raw materials and dosage forms of nettle: Author. diss. Candidate of pharmaceutical sciences]. Moscow, 2013, 23 p. (in Russ.).

28. Pecuha V.S. Farmakognosticheskoe izuchenie krapivy konoplevoj (Urtica cannabina L.): avtoref. kand. farm. nauk. [Farmakognostichesky studying Konopleva nettle (Urtica cannabina L.): Author. diss. Candidate of pharmaceutical sciences.]. Ulan-Udje, 2009, 26 p. (in Russ.). 